(0) Entomologica Fennica. 5 December 1995

\title{
Effects of clear-cutting and selective felling in Swedish Boreal coniferous forest: response of invertebrate taxa eaten by birds
}

\author{
Ola Atlegrim \& Kjell Sjöberg
}

Atlegrim, O. \& Sjöberg, K. 1995: Effects of clear-cutting and selective felling in Swedish Boreal coniferous forest: response of invertebrate taxa eaten by birds. — Entomol. Fennica 6:79-90.

Our aim was to analyse the short-term effects ( $0-4$ years) of selective felling and clear-cutting on the food resources of insectivorous birds. Literature data on bird diets showed that herbivorous larvae (Lepidoptera and Hymenoptera: Symphyta) and spiders (Araneae) were used by 81 and 50\%, respectively, of 16 bird species breeding in the Swedish boreal coniferous forest. A field study comparing selective fellings, clear-cuttings and uncut controls showed considerable effects of clear-cutting on both terricolous and field layer invertebrates. Clear-cuttings had significantly lower abundance and biomass, and a different composition of herbivorous larvae and spiders, as well as a lower total biomass of invertebrates in the field layer than controls. Drastic changes of abiotic factors (like increased temperature range) following clear-cutting may directly affect the occurrence of invertebrates. However, indirect effects (like increased sun exposure, affecting food plant quality for herbivorous larvae) are probably also responsible. Selective fellings did not differ from controls in the occurrence of herbivorous larvae and spiders. Therefore, over the four-year term of our study, selective felling seems to provide birds with conditions similar to uncut forest for invertebrates used by birds.

Ola Atlegrim \& Kjell Sjöberg, Dept. of Animal Ecology, Swedish University of Agricultural Sciences, S-901 83 Umeå, Sweden

\section{Introduction}

In Sweden, clear-cutting is the dominant silvicultural practice and is used everywhere. This extensive use of clear-cutting has resulted in considerable effects on the invertebrate fauna (e.g. Heliövaara \& Väisänen 1984). During harvest the whole tree layer is removed, and this creates an exposed habitat with an increased temperature range, decreased shade, etc. (Geiger 1961, Heliövaara \& Väisänen 1984). The forest field layer is also drastically changed in many cases from predominantly deciduous dwarf shrubs to grasses. It may take con- siderable time before conditions resembling the original forest return. Clear-cutting results in significant changes in the terricolous (i.e. invertebrates living mainly on, and to some extent in, the ground) and field layer invertebrates (Heliövaara \& Väisänen 1984).

The effects of clear-cutting have mostly been interpreted in terms of effects on threatened species, biodiversity, etc. Many invertebrates have a central position in food chains, constitute prey for higher trophic levels, and act as herbivores, predators, parasitoids, etc. on lower trophic levels. Therefore, the changes in the invertebrate 
fauna following forest harvest may also have implications for these trophic levels, and thus for biodiversity as a whole. Changes in composition of the invertebrate fauna or reduced abundance and biomass of important prey groups following clearcutting, may affect the availability of prey and be of importance for insectivorous birds. For example, Stuen \& Spids $\varnothing$ (1988) pointed out that the growth and survival of grouse chicks may be negatively affected by clear-cutting. Food supply is also generally considered an important factor determining clutch size, timing of breeding and reproductive success in birds (Lack 1968, Klomp 1970, Blondel et al. 1987, Martin 1987, Thiollay 1988). The large leaf-eating Lepidoptera larvae, which have been suggested to be of general importance for forest birds (Kaczmarek et al. 1981, Holmes 1990, Tomialojc \& Wesolowski 1990), are found in high numbers in the shrub layer in northern Swedish boreal coniferous forests (Atlegrim 1991, 1992). Many bird species also devote a large proportion of their foraging to the field layer in boreal coniferous forests (von Haartman 1954, Alatalo \& Alatalo 1979, Atlegrim 1992) where they feed on the leafeating Lepidoptera larvae (Atlegrim 1989, 1991). Since the field layer is severely affected by clearcutting (Atlegrim \& Sjöberg a, submitted), the Lepidoptera larvae may also be negatively affected, and this could have an effect on the food availability for insectivorous birds.

Realizing of the negative effects of clearcutting has lead to a growing interest in other silvicultural practices. One of the few well developed alternatives to clear-cutting is single tree selection felling (Daniel et al. 1979; hereafter called "selective felling"). Selective felling is particularly useful in uneven, multi-layered forest stands. With this practice single trees are selected and the trees to be cut are spread out evenly over tree age classes. The stand is naturally regenerated by the growth of young trees. In this practice an intact, although thinned, tree layer will be left after harvesting and this may better preserve the original conditions of the forest before cutting. Because the original conditions are preserved, selective felling may have a lower impact on forest invertebrates as compared to clear-cutting. However, studies on the effects of selective felling are scarce.

The aim of the present study was to analyse the effects of selective felling and clear-cutting on the terricolous and field layer invertebrates which could be important as food for breeding birds. The study consists of three parts: (1) a literature study to provide data on the invertebrate taxa commonly used as food by insectivorous birds, (2) a field investigation to compare the effects of selective felling and clear-cutting on the abundance and biomass of these invertebrate taxa occurring on the forest floor and in the field layer, and (3) a synthesis of the results of the literature study and the field investigation to determine if harvesting might influence food availability for birds.

\section{Methods}

\subsection{Literature study}

Thirteen studies presenting data on diets of bird species which breed in the Swedish Boreal coniferous forest were surveyed with respect to invertebrate taxa included in diets. The proportions of different invertebrate taxa of total biomass consumed by the bird species would probably be the best reflection of energetic importance of an invertebrate taxa to the bird species. However, the studies only provided data on the number of individuals of different invertebrate taxa taken by the bird species. Our survey therefore concentrated on the proportions of different prey taxa taken by the bird species. Only prey groups constituting more than $10 \%$ of the total number of prey taken were accepted as constituting a prey taxa in the diet of the bird species. This excluded taxa only represented by a few individuals.

\subsection{Field study}

\subsubsection{Study area}

The field study was conducted in Åsele Lappmark (Swedish Laplands), $90 \mathrm{~km} \mathrm{NV}$ of Vilhelmina, in the mountain range in the vicinity of lake Bielite $\left(64^{\circ} 55^{\prime} \mathrm{N}, 15^{\circ} 30^{\prime} \mathrm{E}\right)$. The lake is $487 \mathrm{~m}$ above sea level and in an area where the coniferous tree line is about $700 \mathrm{~m}$ above see level. The area belongs to the northern Boreal region (Ahti 
et al. 1968). The bedrock consists of eokambrian sandstone and the soil varies from sand/fine sand to gravel till. The mean precipitation is about $750 \mathrm{~mm}$ per year, and the mean length of vegetation period is about 120 days (Ångström 1974). Snow normally covers the ground from the beginning of October until the end of May (about 200 days). The entire region had been logged with diameter limit cutting (cuttings restricted to large, old coniferous trees with wide diameters), once or twice in historic time.

Three mature forest areas of mesic Vaccinium myrtillus-type, dominated by spruce (Picea abies) were used for the study. Each forest area was sub-divided into three stands of about 20 ha each. Within each forest area, one stand was randomly selected for one of the three following treatments: (1) one stand was left uncut as a control, (2) one stand was clear-cut and (3) one stand was cut with selective felling, so that each treatment was represented by one stand in each of the three forest areas. In the selective felling treatment ca $30 \%$ of the tree numbers were removed $(45-50 \%$ of the tree volume). The cutting was distributed over all age classes of trees. Following conventional practice, the whole tree layer was removed in the clear-cuttings, followed by surface scarification and artificial regeneration. The treatments were staggered in time, and when this study was conducted (in 1992), the oldest cuttings were four years old and the youngest was done in the winter preceding the study.

\subsubsection{Sampling and analyses}

Ten sites were randomly located in each of the nine stands. All sampling was conducted at these sites although with varying number of samples (see below). One pitfall trap was randomly placed at each site. Plastic jars, $7 \mathrm{~cm}$ high and $7 \mathrm{~cm}$ in diameter were half filled with a 1:1 mixture of ethylene glycol and water, and a small amount of surfacetension reducer (dish washing detergent). The traps were out June 13 to July 21992 . We used the pitfall trap data as a measure of relative occurrence of invertebrate taxa (no lower than family level) to compare the treatments, and not as a measure of numerical species composition (compare Topping and Sunderland 1992). Topping \& Sunderland
(1992) showed that there were high correspondence between spiders densities as measured by density samples and pitfall traps for the time of season corresponding to our study. Törmälä (1982) found that the pitfall trapping method gave fairly reliable results on relative occurrence of both spiders and other invertebrate taxa. This has also been shown for beetles in forest habitats (Niemelä et al. 1988). Activity of the prey might be an important factor for detection by birds and since pitfall data is a combination of both invertebrate abundance and their activity, pitfall traps may best reflect the availability of prey for birds than other sampling methods.

At each site and in the vicinity of each pitfall trap, three sweep-net (diameter $0.25 \mathrm{~m}$ ) samples were taken. Each sample consisted of twenty sweeps moving along in the field layer. The samples were taken, by the same person, between June 29 and July 2. Invertebrates were preserved in $70 \%$ alcohol. Sweep-net sampling could be influenced by weather conditions so all sampling was conducted on sunny warm days. Furthermore, all sampling within a forest area was conducted the same day. In a parallel study, conducted at the same sites as in this study, the number of herbivorous larvae were counted visually within $10 \mathrm{dm}^{-2}$ rings laid out in the field layer (Atlegrim \& Sjöberg b, submitted). These data show a close correspondence in abundance between the treatments to the sweep-net data of the present study. Thus, it appears that sweep-net sampling gives an accurate measure of the occurrence of invertebrates in the field layer in the stands (treatments) studied here.

There are reasons to analyse lower taxonomic levels than orders because earlier studies of invertebrate responses to forest harvest have shown responses at these lower levels. Thus, for the field layer material (sweep-net) money-spiders (Linyphiidae; which build webs in the field layer vegetation), were analysed separately, and the ground layer material (pitfall traps) was divided into wolf-spiders (Lycosidae; active hunters) as well as money-spiders. Atlegrim (1992) showed that there were great differences in the risk of being preyed upon by pied flycatchers (Ficedula hypoleuca) between different types of herbivorous larvae. Following Atlegrim (1992) these larvae were therefore divided into two groups: 1) 
exposed larvae (which crawl on leaves while feeding and include geometrids, noctuids, lasiocampids (Lepidoptera) and sawfly larvae (Hymenoptera: Symphyta) and 2) concealed larvae, which spins leaves together and live between these leaves and include tortricids and pyralids (Lepidoptera). Further, terricolous beetles (Coleoptera) were divided into ground beetles (Carabidae) and rove beetles (Staphylinidae). For each taxonomic group and sample, all individuals belonging to a group were first counted and then weighed together as a composite sample to the nearest $0.001 \mathrm{~g}$.

For the sweep-net samples a mean value of the three samples was calculated for each site. In the sweep-net data the abundance and biomass in the field layer was analysed in the following taxa: beetles, concealed larvae, exposed larvae, herbivorous larvae, money spiders, spiders, flies (Diptera) and true bugs (Hemiptera). In the pitfall data the abundance and biomass was analysed in the following terricolous taxa: ground beetles, rove beetles, beetles, money spiders, wolf spiders, spiders, ants (Hymenoptera: Formicidae) and flies. The effects of forest practices were analysed with a randomised block ANOVA where forest area constituted the block effect and treatment (i.e. uncut control, selective felling and clear-cutting) the effect of forest harvest. If treatment had a significant effect on the occurrence of an invertebrate taxa, the differences between treatments were tested with a Tukey test (Zar 1984). The assumptions of the ANOVA analysis (i.e. normality and homogeneity) were analysed with the Lilliefors test and by plotting residuals against factors (treatment and forest area) and predicted values (Wilkinson 1987). Raw data could be used for the abundance of terricolous ground beetles, and for field layer abundance of beetles, concealed larvae, spiders and true bugs, and biomass of concealed larvae. However, to fulfil the assumptions of the ANOVA, squareroot-transformation:

$$
\text { square-root }(\mathrm{X}+1)
$$

were used for the abundance of terricolous rove beetles and the field layer biomass of spiders and flies, while biomass of terricolous ants was rank-transformed, all other data were log transformed:

$$
\log (\mathrm{X}+1)
$$

\section{Results}

In the thirteen studies surveyed, data on diet could be obtained for 16 bird species breeding in the Swedish Boreal coniferous forest (Table 1). The bird species feed on several invertebrate taxa, but often one or a few taxa dominated and these often constituted more than $80 \%$ of the number of prey taken. Of the 16 bird species for which data could be compiled $81 \%$ used Lepidoptera larvae. The second commonest prey item was spiders (Araneae) taken by $50 \%$ of the birds species; the use of beetles, ants, sawfly larvae, flies and true bugs were lower (Table 1).

The only statistically significant effect of forestry practices (treatment) on terricolous invertebrates was on the abundance and biomass of wolf spiders (Table 2). The abundance and biomass were significantly higher in clear-cuts than in both uncut controls and selective fellings (Fig. 1). Harvesting practice had significant effects on both abundance and biomass of exposed larvae, herbivorous larvae (total), money spiders and spiders (total) occurring in the field layer (Table 2). There was also a significant effect on total invertebrate biomass in the field layer (Table 2). Exposed larvae had significantly higher abundance and biomass in uncut controls and selective fellings than in clear-cuttings (Fig. 2). The same pattern was found in the abundance and biomass of herbivorous larvae (exposed and concealed larvae combined; Fig. 2). Money spiders had significantly higher abundance and biomass in controls than in clear-cuttings (Fig. 2). The total abundance and biomass of spiders showed a similar pattern (Fig. 2).

\section{Discussion}

Thiollay (1988) showed that the diet of tropical and temperate birds differed considerably. For birds breeding in tropical forests the diet was quite varied, while $88 \%$ of the diet of temperate forest breeding birds were larvae (of which $73 \%$ were Lepidoptera larvae). For bird species breeding in the boreal coniferous forests, Lepidoptera larvae also constitute a prey used by several birds (Table 1). Our literature study (Table 1) included studies conducted both in temperate deciduous 
Table1. Prey insect taxa, each of which constitute at least $10 \%$ of the total number of prey taken by different bird species breeding in Swedish boreal coniferous forests. Data compiled from: von Haartman (1954), Betts (1955), Tinbergen (1960), Meidell (1961), Gibb \& Betts (1963), Royama (1970), Spidsø (1980), Kaczmarek et al. (1981), Erikstad \& Spidsø (1982), Stuen (1983), Silverin \& Andersson (1984), Kastdalen (1986) and Spidsø \& Stuen (1988).

\begin{tabular}{|c|c|c|c|c|c|c|c|}
\hline Bird species & Spiders & $\begin{array}{c}\text { Lepido- } \\
\text { ptera larvae }\end{array}$ & Flies & Beetles & Ants & $\begin{array}{l}\text { Sawfly } \\
\text { larvae }\end{array}$ & Bugs \\
\hline
\end{tabular}

\section{Pied flycatcher \\ Ficedula hypoleuca}

Redstart

Phoenicurus phoenicurus

Robin

$\begin{array}{lll}x & x & x \\ x & x\end{array}$

Erithacus rubecula $x$

Parus major

Blue tit

$P$. caeruleus

Coal tit

$P$. ater

Willow tit

P. montanus

Blackcap

Sylvia atricapilla

Chiffchaff

Phylloscopus collybita

Wood warbler

P. sibilatrix

Blackbird

Turdus merula

Song trush

T. philomelos

\section{Chaffinch}

Fringilla coelebs

Willow grouse

Lagopus lagopus

Black grouse

Lyrurus tetrix

$x$
Capercaillie

Tetrao urogallus $x$

$x$

$x \quad x$

$\mathrm{X}$

$x$

$\mathrm{X}$

$\mathrm{x}$

$x$

$x$

$x$

$x$

$x$

$x$

$x \quad x \quad x$

$x \quad x$

$x$

$x$

$x$

$x$

$x$

$x$

$x$

$x$

$x \quad x$

$x$

$x$

$x$

$x$

x

X

$x$

$x$

Percentage of bird species

feeding on the taxa

50

81

31

44

37

37

and in boreal coniferous forests. Comparing these studies for the same bird species showed a high correspondence in the diets. This indicates that there is a higher correspondence in bird diets between birds breeding in temperate deciduous and boreal coniferous forest than there seems to be between birds breeding in temperate and tropical forests (Thiollay 1988). Besides herbivorous 


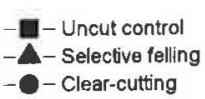

Abundance

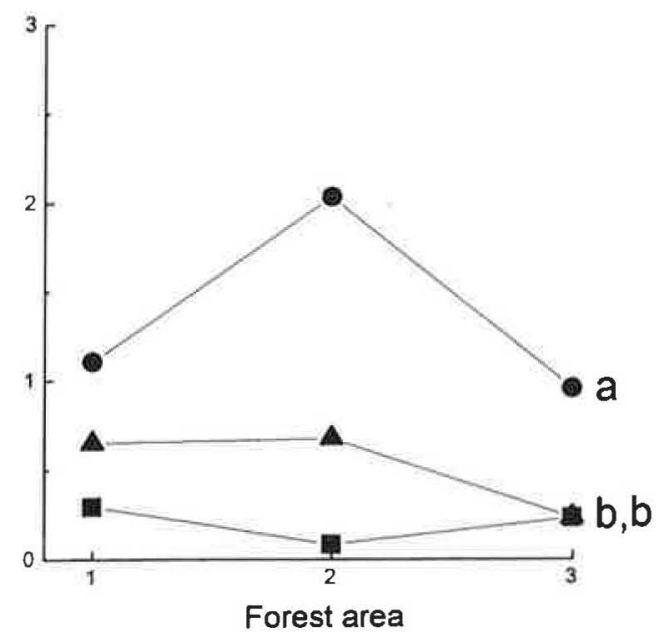

Biomass

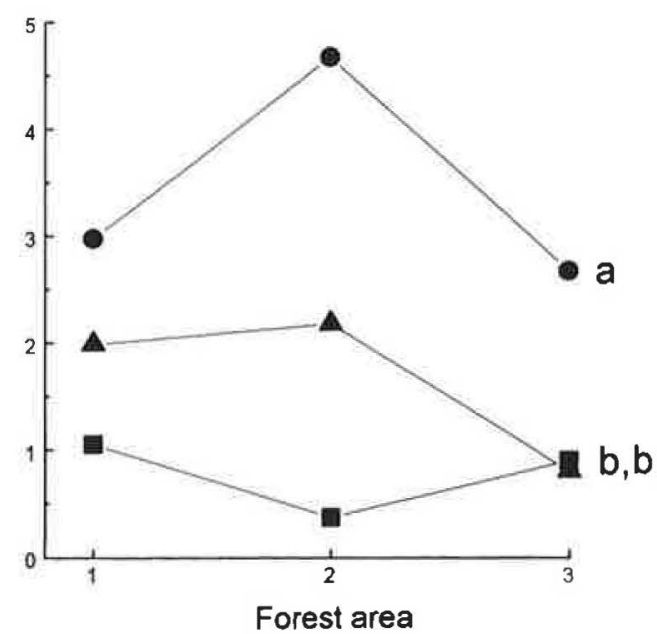

Fig. 1. Mean abundance and biomass ( $\mathrm{mg}$ ) of terricolous wolf spiders (Lycosidae) in uncut control stands and in stands harvested with selective felling and clear-cutting in three forest areas (forest number). Each value represents a mean value of ten pitfall traps. Lines between the treatment values in the different forest areas are drawn to simplify comparisons between treatments and shifts in the order of treatments between forest areas, as well as to indicate effects of forest area. Different letters at the right of the different treatments indicate a significant difference between treatments $(\alpha<0.05$, Tukey test). The values shown are log-transformed values.

larvae, our literature study of bird diets showed that a high proportion of the birds also ate spiders (Table 1). Interestingly, these were also the two invertebrate taxa for which we found considerable effects of forest harvest (Table 2).

Exposed larvae, mainly geometrids (Lepidoptera) and sawflies (Hymenoptera: Symphyta), dominated among the herbivorous larvae in the field layer. The exposed larvae have earlier been shown to have a higher risk of being preyed upon by pied flycatchers (Ficedula hypoleuca; Atlegrim 1992). While feeding the larvae crawl on the leaves thereby exposing themselves to bird predators. This probably explains their high predation risk (Atlegrim 1992). Bird exclosure studies also show that these exposed larvae are taken in high numbers by birds (Atlegrim 1989, 1991). Since the weight of an exposed larvae is high they could constitute an important prey for bird species during their breeding season (MacArthur 1959, Royama 1970, Kaczmarek et al. 1981, Robinsson \& Holmes 1982, Holmes
1990, Tomialojc \& Wesolowski 1990).

The abundance and biomass of exposed larvae was significantly lower in clear-cuttings than in selective fellings and uncut controls (Fig. 2). Direct effects of increased temperature and moisture amplitudes following clear-cutting (e.g. Geiger 1961, Heliövaara \& Väisänen 1984) may decrease the survival of the exposed larvae (e.g. Holliday 1985) and explain these differences. However, increased sun exposure following clear-cutting also increases the phenol content in bilberry (Vaccinium myrtillus), the larval food-plant (Atlegrim \& Sjöberg a, submitted). This may decrease food quality of the bilberry by constraining nitrogen uptake by larvae (Feeny 1968, 1970). Thus, the changes in abiotic factors following clear-cutting may also have indirect, negative effect on the exposed larvae through changes in food quality.

In selective fellings the abiotic factors did not change as dramatically as in clear-cuttings (Atlegrim \& Sjöberg a, submitted). The phenol 


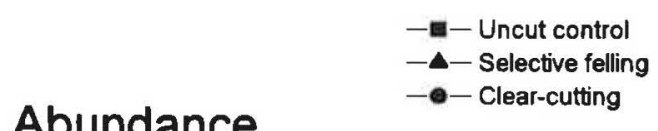

Abundance
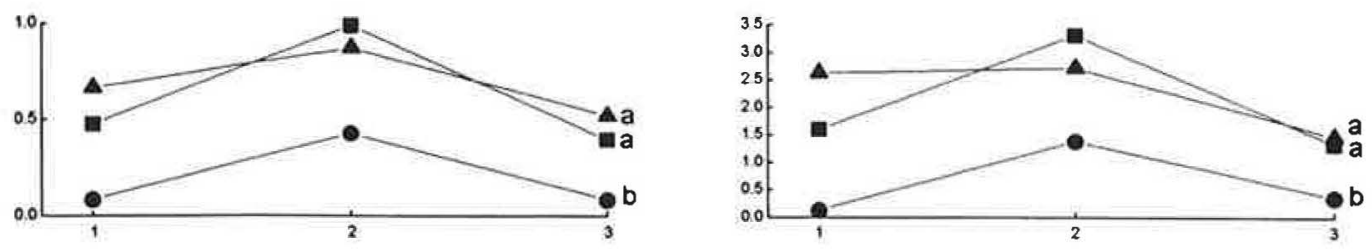

Total: herbivorous larvae
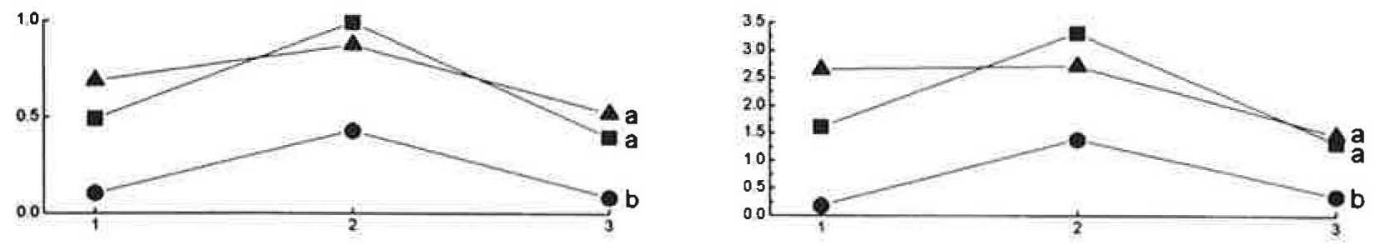

Money-spiders
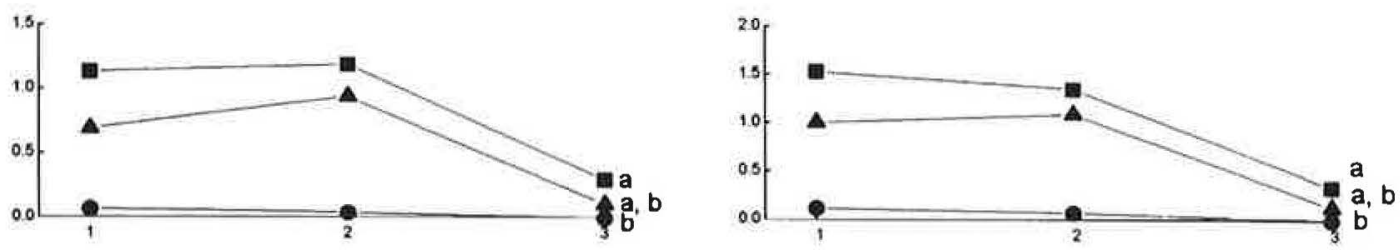

Total: Spiders
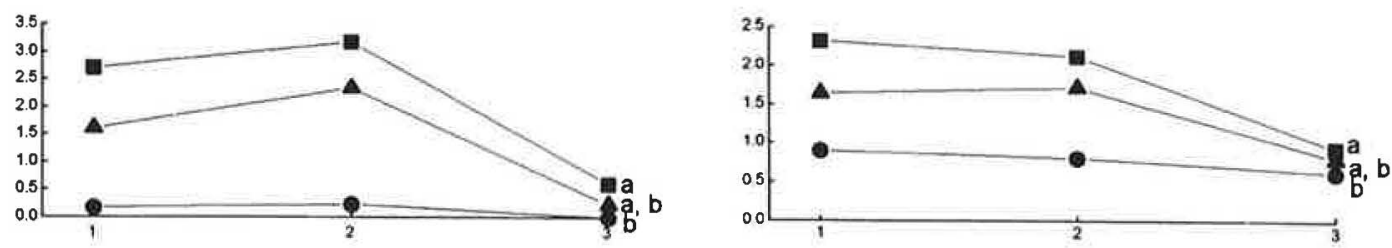

Total: Invertebrates
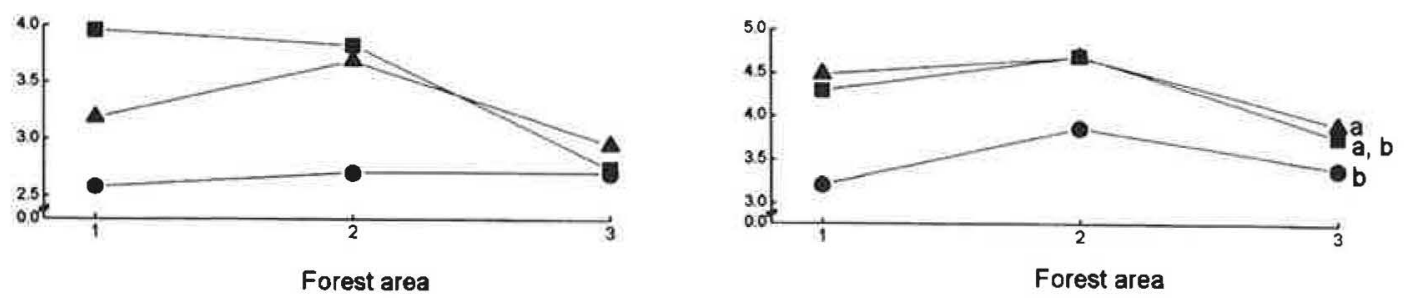

Fig. 2. Mean abundance and biomass $(\mathrm{mg})$ of herbivorous, exposed larvae, geometrids and sawflies (Lepidoptera and Hymenoptera: Symphyta), total herbivorous larvae (i.e. exposed larvae plus tortricids and pyralids (Lepidoptera)), money spiders (Linyphiidae), spider total (Araneae) and invertebrates total, in the field layer of uncut stands and stands harvested with the selective felling and clear-cutting practices in three forest areas (forest number). All values shown are log-transformed values except for spider abundance for which original values are shown. Otherwise as in Fig. 1. 
content in bilberry did not differ between selective fellings and uncut controls (Atlegrim \& Sjöberg a, submitted). Thus, the direct effects on the herbivorous larvae of changes in abiotic factors and the indirect effects of changes in food plant quality may be more moderate in selective fellings. This could explain the low effect of selective felling on these exposed larvae. Further, it may also explain the significant difference in abundance and biomass of the exposed larvae between selective fellings and clearcuttings (Fig. 2). Because the exposed larvae dominated among the herbivorous larvae the total abundance and biomass of herbivorous larvae followed the pattern of exposed larvae.

The decrease of money-spiders and increase of wolf-spiders found in our study following clear- cutting have also been reported by other studies (Huhta 1971, Coyle 1981, Mclver et al. 1992, Pajunen et al. 1995). Huhta (1971) suggested that the reason for this is increased solar radiation on clear-cuttings causing extreme temperatures and dryness, unfavourable to species prevailing in shaded forests which have a low heat tolerance. Another contributing factor, especially for money-spiders, on the clear-cuts studied by us may be the considerable decrease in the ground cover of dwarf shrubs which following clearcutting was replaced by bare ground (Atlegrim \& Sjöberg a, submitted). This might decrease the opportunity for money-spiders to spin webs and further decrease habitat quality for this spider group. Instead, conditions for the visually hunting wolf-spiders may be improved. However, the

Table 2. Effects of forest harvest (i.e. treatment; selective felling, clear-cutting and uncut control) and forest area (block effect; three forest areas) analysed with randomised block ANOVA.

\begin{tabular}{|c|c|c|c|c|c|c|c|c|c|c|}
\hline \multicolumn{2}{|l|}{ Taxa } & $\mathrm{MS}_{\text {treatment }}$ & $\mathrm{df}$ & $\mathrm{p}$ & $\mathrm{MS}_{\text {area }}$ & $\mathrm{df}$ & $p$ & $\mathrm{MS}_{\text {error }}$ & $\mathrm{df}$ & $\mathrm{R}^{2}$ \\
\hline \multicolumn{11}{|l|}{ Terricolous fauna } \\
\hline \multirow{2}{*}{$\begin{array}{l}\text { Ground beetles } \\
\text { (Carabidae) }\end{array}$} & abund. & 4.138 & 2 & 0.163 & 0.174 & 2 & 0.889 & 1.436 & 4 & 0.600 \\
\hline & biom. ${ }^{1}$ & 1.600 & 2 & 0.214 & 0.211 & 2 & 0.752 & 0.689 & 4 & 0.568 \\
\hline \multirow{2}{*}{$\begin{array}{l}\text { Rove beetles } \\
\text { (Staphylinidae) }\end{array}$} & abund. ${ }^{2}$ & 1.009 & 2 & 0.547 & 3.399 & 2 & 0.209 & 1.432 & 4 & 0.606 \\
\hline & biom. ${ }^{1}$ & 0.113 & 2 & 0.780 & 0.520 & 2 & 0.387 & 0.428 & 4 & 0.425 \\
\hline \multirow{2}{*}{$\begin{array}{l}\text { Beetles total } \\
\text { (Coleoptera) }\end{array}$} & abund. ${ }^{1}$ & 0.097 & 2 & 0.666 & 0.498 & 2 & 0.214 & 0.214 & 4 & 0.581 \\
\hline & biom. ${ }^{1}$ & 0.481 & 2 & 0.240 & 0.005 & 2 & 0.980 & 0.231 & 4 & 0.512 \\
\hline \multirow{2}{*}{$\begin{array}{l}\text { Money spiders } \\
\text { (Linyphiidae) }\end{array}$} & abund. ${ }^{1}$ & 0.284 & 2 & 0.257 & 0.023 & 2 & 0.857 & 0.146 & 4 & 0.513 \\
\hline & biom. ${ }^{1}$ & 0.580 & 2 & 0.168 & 0.265 & 2 & 0.364 & 0.202 & 4 & 0.677 \\
\hline \multirow{2}{*}{$\begin{array}{l}\text { Wolf spiders } \\
\text { (Lycosidae) }\end{array}$} & abund. ${ }^{1}$ & 1.088 & 2 & 0.036 & 0.164 & 2 & 0.371 & 0.128 & 4 & 0.830 \\
\hline & biom. ${ }^{1}$ & 5.549 & 2 & 0.030 & 0.716 & 2 & 0.384 & 0.584 & 4 & 0.843 \\
\hline \multirow{2}{*}{$\begin{array}{l}\text { Spiders total } \\
\text { (Araneae) }\end{array}$} & abund. ${ }^{1}$ & 0.042 & 2 & 0.609 & 0.071 & 2 & 0.457 & 0.074 & 4 & 0.432 \\
\hline & biom. ${ }^{1}$ & 0.326 & 2 & 0.115 & 0.558 & 2 & 0.053 & 0.084 & 4 & 0.841 \\
\hline \multirow{2}{*}{$\begin{array}{l}\text { Ants (Hymeno- } \\
\text { ptera: Formicidae) }\end{array}$} & abund. ${ }^{1}$ & 0.021 & 2 & 0.304 & 0.006 & 2 & 0.640 & 0.013 & 4 & 0.515 \\
\hline & biom. ${ }^{3}$ & 84.163 & 2 & 0.315 & 14.916 & 2 & 0.772 & 53.917 & 4 & 0.479 \\
\hline \multirow{2}{*}{$\begin{array}{l}\text { Flies } \\
\text { (Diptera) }\end{array}$} & abund. ${ }^{1}$ & 0.116 & 2 & 0.357 & 0.131 & 2 & 0.323 & 0.086 & 4 & 0.589 \\
\hline & biom. ${ }^{1}$ & 0.043 & 2 & 0.670 & 0.061 & 2 & 0.579 & 0.097 & 4 & 0.349 \\
\hline \multirow[t]{2}{*}{ Total } & abund. ${ }^{-1}$ & 0.016 & 2 & 0.856 & 0.052 & 2 & 0.649 & 0.108 & 4 & 0.241 \\
\hline & biom. 1 & 0.123 & 2 & 0.637 & 0.112 & 2 & 0.660 & 0.242 & 4 & 0.362 \\
\hline
\end{tabular}


Table 2. continued

\begin{tabular}{|c|c|c|c|c|c|c|c|c|c|c|}
\hline Taxa & & $\mathrm{MS}_{\text {treatment }}$ & $d f$ & $p$ & $\mathrm{MS}_{\text {area }}$ & df & $p$ & $\mathrm{MS}_{\text {error }}$ & $d f$ & $\mathrm{R}^{2}$ \\
\hline \multicolumn{11}{|l|}{ Field layer fauna } \\
\hline \multirow{2}{*}{$\begin{array}{l}\text { Beetles } \\
\text { (Coleoptera) }\end{array}$} & abund. & 0.418 & 2 & 0.557 & 0.291 & 2 & 0.654 & 0.615 & 4 & 0.366 \\
\hline & biom. ${ }^{1}$ & 0.144 & 2 & 0.636 & 0.089 & 2 & 0.747 & 0.283 & 4 & 0.291 \\
\hline \multirow{2}{*}{$\begin{array}{l}\text { Concealed larvae } \\
\text { (Lepidoptera: Tortrici- } \\
\text { dae \& Pyralidae) }\end{array}$} & abund. & 0.000 & 2 & 0.444 & 0.002 & 2 & 0.012 & 0.000 & 4 & 0.895 \\
\hline & biom. ${ }^{2}$ & 0.075 & 2 & 0.444 & 0.415 & 2 & 0.070 & 0.075 & 4 & 0.766 \\
\hline \multirow{2}{*}{$\begin{array}{l}\text { Exposed larvae (Lepi- } \\
\text { doptera: Geometridae } \\
\text { \& Hymenoptera: } \\
\text { Symphyta) }\end{array}$} & abund. ${ }^{1}$ & 0.210 & 2 & 0.005 & 0.159 & 2 & 0.008 & 0.008 & 4 & 0.958 \\
\hline & biom. ${ }^{1}$ & 2.428 & 2 & 0.027 & 1.587 & 2 & 0.054 & 0.241 & 4 & 0.893 \\
\hline \multirow{2}{*}{$\begin{array}{l}\text { Herbivorous larvae } \\
\text { total }\end{array}$} & abund. 1 & 0.209 & 2 & 0.005 & 0.154 & 2 & 0.009 & 0.008 & 4 & 0.956 \\
\hline & biom. ${ }^{1}$ & 2.394 & 2 & 0.027 & 1.573 & 2 & 0.054 & 0.237 & 4 & 0.893 \\
\hline \multirow{2}{*}{$\begin{array}{l}\text { Money spiders } \\
\text { (Linyphiidae) }\end{array}$} & abund. ${ }^{1}$ & 0.539 & 2 & 0.039 & 0.297 & 2 & 0.095 & 0.066 & 4 & 0.863 \\
\hline & biom. ${ }^{-1}$ & 0.790 & 2 & 0.041 & 0.492 & 2 & 0.083 & 0.100 & 4 & 0.865 \\
\hline \multirow{2}{*}{$\begin{array}{l}\text { Spiders total } \\
\text { (Araneae) }\end{array}$} & abund. & 3.127 & 2 & 0.047 & 2.156 & 2 & 0.082 & 0.432 & 4 & 0.860 \\
\hline & biom. ${ }^{2}$ & 0.784 & 2 & 0.040 & 0.646 & 2 & 0.054 & 0.098 & 4 & 0.879 \\
\hline \multirow{2}{*}{$\begin{array}{l}\text { Flies } \\
\text { (Diptera) }\end{array}$} & abund. ${ }^{1}$ & 1.158 & 2 & 0.125 & 0.226 & 2 & 0.543 & 0.316 & 4 & 0.687 \\
\hline & biom. ${ }^{2}$ & 2.509 & 2 & 0.199 & 0.872 & 2 & 0.488 & 1.009 & 4 & 0.626 \\
\hline \multirow{2}{*}{$\begin{array}{l}\text { True bugs } \\
\text { (Hemiptera) }\end{array}$} & abund. & 4.805 & 2 & 0.167 & 0.821 & 2 & 0.643 & 1.665 & 4 & 0.628 \\
\hline & biom. ${ }^{1}$ & 0.209 & 2 & 0.224 & 0.137 & 2 & 0.335 & 0.094 & 4 & 0.648 \\
\hline \multirow[t]{2}{*}{ Total } & abund. ${ }^{1}$ & 0.569 & 2 & 0.116 & 0.294 & 2 & 0.250 & 0.147 & 4 & 0.746 \\
\hline & biom. ${ }^{1}$ & 0.671 & 2 & 0.016 & 0.401 & 2 & 0.037 & 0.048 & 4 & 0.918 \\
\hline
\end{tabular}

1 Analysis done on log-transformed values: $\log (x+1))$

2 Analysis done on square-root-transformed values: square-root $(x+1)$

3 Analysis done on rank-transformed values

increase of wolf-spiders did not seem to compensate the decrease found for the total spider abundance biomass in the field layer. Thus, for the spider fauna as a whole (both terricolous and field layer) the results indicate that clear-cutting had a negative effect on the abundance of spiders.

In contrast, the spider fauna in selective fellings did not significantly differ from that in uncut control forests (Fig. 1 and 2). Although there were indications of a decreased occurrence of money-spiders in the field layer, the data indicated a higher abundance and biomass of terricolous spiders in the selective fellings compared to the uncut controls (cf. Fig. 1 and 2).
Lepidoptera larvae and spiders constituted over $40 \%$ of the total biomass of invertebrates in the field layer in selective fellings and uncut controls but only $27 \%$ in the clear-cuttings. In temperate deciduous forests, folivorous Lepidoptera larvae constitute the major part of the diet of many forest birds, especially during their breeding season (MacArthur 1959, Royama 1970, Kaczmarek et al. 1981, Robinson \& Holmes 1982, Thiollay 1988). In the temperate deciduous forests these larvae are found in high numbers in the tree layer (Patocka \& Capek 1971, Kaczmarek \& Wasilewski 1977, Holmes \& Schultz 1988), and birds devote a high propor- 
tion of their food search to the tree layer in these forests (Edington \& Edington 1972).

Our literature study on diets of birds breeding in the Swedish boreal coniferous forest showed that Lepidoptera larvae are used by a majority of the bird species (Table 1). The Lepidoptera larvae often constitute a high proportion of the diet of different bird species. Since the biomass of these folivorous larvae is high it seems reasonable that they also constitute a high proportion of the biomass consumed by the birds. The food chain (from plants, herbivorous larvae to birds feeding on the larvae) is to a large extent based on the field layer in Swedish boreal coniferous forests (Atlegrim 1992). In the boreal coniferous forest the folivorous Lepidoptera larvae (in many cases the same species as in the tree layer in the temperate forest) feed on bilberry (Vaccinium myrtillus), the dominant plant in the field layer ( $\Lambda$ tlegrim 1991). Birds also devote a large proportion of their foraging to the field layer in boreal coniferous forests (von Hartman 1954, Alatalo \& Alatalo 1979, Atlegrim 1992), while a large proportion of foraging is devoted to the tree layer in temperate deciduous forests (Edington \& Edington 1972). In the Swedish boreal coniferous forests the number of larvae in the bilberry field layer is also greatly reduced by bird predation (Atlegrim 1989, 1991, Atlegrim \& Sjöberg 1995). Silvola (1967) has also shown that insectivorous birds breed in increased densities when the density of folivorous larvae increases. Thus, changes in the abundance of the folivorous Lepidoptera larvae might have important effects on the food availability for birds.

The two main prey groups, the herbivorous Lepidoptera larvae and the spiders (showed to be used by several bird species (Table 1)), were severely reduced after clear-cutting (Figs. 1 and 2 ). This indicates that clear-cutting ought to affect food availability negatively for birds in the short-term (a maximum of 4 years since cutting studied here). Selective felling, on the other hand, did not significantly affect the two main prey groups and seems to provide the birds with an invertebrate prey fauna corresponding to that found in the uncut control forest. Thus, from the perspective of minimising the impact on birds and their main invertebrate prey it seems that selective felling should be chosen in favour of clear-cutting whenever possible. On the other hand, as pointed out by Holmes \& Schultz (1988), the availability of food for forest birds is a function of not only of the type and abundance of preys present. Besides prey occurrence, food availability is also affected by foliage structure and characteristics of the food plant or substrate which influences detectability and accessibility. Prey accessibility is further affected by morphological and behavioural abilities of each bird species to perceive and capture the prey. Our study provides evidence that clear-cutting reduced, but selective felling had no effect on the abundance and biomass of the two main invertebrate prey taxa used by many birds. Further studies are, however, needed to analyse the other functions of food availability for birds. Specifically the long-term effects on the abundance, biomass and composition of prey for the two silvicultural practices considered here, need to be studied.

Acknowledgements. We are grateful to Mats Jonsson for field assistance. John P. Ball and Mats Lindén gave valuable comments on earlier versions of the manuscript. We are also grateful to Leif Hemberg for help with selection of stands and to the common forest owners (Vilhelmina allmänning) for allowing us performing studies in their forests. The study was financially supported by the Faculty of Forestry at the Swedish University of Agricultural Sciences, Sweden.

\section{References}

Ahti, T., Hämet-Ahti, L. \& Jalas, J. 1968: Vegetation zones and their sections in northwestern Europe. Ann. Bot. Fenn. 5: 169-211.

Alatalo, R. V. \& Alatalo, R. H. 1979: Resource partitioning among a flycatcher guild in Finland. - Oikos 33: $46-54$.

Ångström, A. 1974: Sveriges klimat. - Generalstabens litografiska anstalts förlag, Stockholm, Sweden. 188 pp. (in Swedish)

Atlegrim, O. 1989: Exclusion of birds from bilberry stands: impact on insect larval density and damage to the bilberry. - Oecologia 79: 136-139.

- 1991: Interactions between the bilberry (Vaccinium myrtillus) and a guild of insect larvae in a boreal coniferous forest. - Dissertation, Report 19, Dept. of Wildlife Ecology, Swedish University of Agricultural Sciences, Umeă. 158 pp.

- 1992: Mechanisms regulating bird predation on a herbivorous larva guild in boreal coniferous forests. Ecography 15: 19-24. 
Atlegrim, O. \& Sjöberg, K. 1995: Lepidoptera larvae as food for capercaillie chick (Tetrao urogallus): a field experiment. - - Scand. J. For. Res. (in press).

- a: Effects of clear-cutting and selective felling in Swedish boreal coniferous forest. I. Response of the dominant field layer plant bilberry (Vaccinium myrtillus). — Forest Ecol. \& Managment (submitted).

- b: Effects of clear-cutting and selective felling in Swedish boreal coniferous forest. II. Response of herbivorous insect larvae. - Forest Ecol. \& Managment (submitted).

Betts, M. M. 1955: The food of titmice in oak woodland. - J. Anim. Ecol. 24: 282-323.

Blondel, J., Clamens, A., Cramm, P., Gaubert, H. \& Isenmann, P. 1987: Population studies on Tits in the Mediterranean region. - Ardea 75: 35-42.

Coyle, F. A. 1981: Effects of clear-cutting on the spider community of a southern Appalachian forest. - $\mathbf{J}$. Arachnol. 9: 285-298.

Daniel, T. W., Helms, J. A. \& Baker, F. S. 1979: Principles of silviculture. 2nd ed. - McGraw-Hill Book Company, New York, USA. 500 pp.

Edington, J. M. \& Edington, M. A. 1972: Spatial patterns and habitat partition in the breeding birds of upland wood. - J. Anim. Ecol. 41: 331-357.

Erikstad, K. E. \& Spids $\varnothing$, T. K. 1982: The influence of weather on food intake, insect prey selection and feeding behaviour in willow grouse chicks in northern Norway. - Ornis Scand. 13: 176-182.

Feeny, P. P. 1968: Effects of oak leaf tannins on larval growth of the winter moth Operophtera brumata. - J. Insect Physiol. 14: 805-814.

- 1970: Seasonal changes in oak leaf tannins and nutrients as a cause of spring feeding by winter moth caterpillars. - Ecology 51: 567-581.

Geiger, R. 1961: Das klima der bodennahen Luftschicht. 4th ed. - Braunschweig, $646 \mathrm{pp}$.

Gibb, J. A. \& Betts, M. M. 1963: Food and food supply of nestling tits (Paridae) in Breckland pine. - J. Anim. Ecol. 32: 489-533.

von Haartman, L. 1954: Der Trauerfliegenschnäpper. III. Die Nahrungsbiologie. - Acta Zool. Fenn. 83: 1-96.

Heliövaara, K. \& Väisänen, R. 1984: Effects of modern forestry on northwestern European forest invertebrates - a synthesis. - Acta For. Fenn. 189: 1-32.

Holliday, N. J. 1985: Maintenance of the phenology of the winter moth (Lepidoptera: Geometridae). — Biol. J. Linn. Soc. 25: 221-234.

Holmes, R. T. 1990: Food resource availability and use in forest bird communities: A comparative view and critique. - In Keast, A. (ed.): Biogeography and ecology of forest bird communities. SPB Academic Publishing bv, The Hague, The Netherlands, pp. 387-393.

Holmes, R. T. \& Schultz, J. C. 1988: Food availability for forest birds: effects of prey distribution and abundance on bird foraging. - Can. J. Zool. 66: 720-728.

Huhta, V. 1971: Succession in the spider communities of the forest floor after clear-cutting and prescribed burn- ing. - Ann. Zool. Fennici 8: 483-542.

Kaczmarek, W. \& Wasilewski, A. 1977: Dynamics of numbers of the leaf-eating insects and its effect on foliage production in the "Grabowy" reserve in the Kampinos national park. - Ekol. Pol. 25: 653-673.

Kaczmarek, W., Sierakowski, K. \& Wasilewski, A. 1981: Food preferences of insectivorous birds in forest ecosystems of the Kampinos national park. - Ekol. Pol. 29: 499-518.

Kastdalen, L. 1986: Storfugl- og orrfuglkyllingers naeringvalg i sør-ost Norge. - M. Sc. thesis, University of Oslo, Oslo, Norway. 68 pp. (in Norwegian, English summary).

Klomp, H. 1970: The determination of clutch size in birds. A review. - Ardea 58: 1-124.

Lack, D. 1968: Ecological adaptions for breeding in birds. - Methuen \& Co Ltd, London, 409 pp.

MacArthur, R. H. 1959: On the breeding distribution patterns of North American migrant birds. - Auk 76: 318-325.

Martin, T. E, 1987: Food as a limit on breeding birds: a life-history perspective. - Ann. Rev. Ecol. Syst. 18: 4.5.3-487.

McIver, J. D., Parsons, G. L. \& Mojdenke, A. R. 1992: Litter spider succession after clear-cutting in a western coniferous forest. - Can. J. For. Res. 22: 984 992.

Meidell, O. 1961: Life history of the pied flycatcher and the redstart in a Norwegian mountain area. - Nytt Mag. Zool. 10: 5-49.

Niemelä, J., Haila, Y., Halme, E., Lahti, T., Pajunen, T. \& Punttila, P. 1988: The distribution of carabid beetles in fragments of old coniferous taiga and adjacent managed forest. - Ann. Zool. Fennici 25: 107-119.

Pajunen, T., Haila, Y., Halme, E., Niemelä, J. \& Punttila, P. 1995: Ground-dwelling spiders (Arachnida, Araneae) in fragmented old forests and surrounding managed forests in southern Finland. - Ecography 18: 62-72.

Patocka, J. \& Capek, M. 1971: Population changes of certain oak defoliators (Lepidoptera) in Slovakia. Acta Inst. For. Zvolenensis 2: 461-485.

Robinsson, S. K. \& Holmes, R. T. 1982: Foraging behavior of forest birds: the relationship among search tactics, diet, and habitat structure. - Ecology 63: 1918-1931.

Royama, T. 1970: Factors governing the hunting behaviour and selection of food by great tit (Parus major L.). — J. Anim. Ecol. 39: 619-668.

Silverin, B. \& Andersson, G. 1984: Föda hos svartvita flugsnappare Ficedula hypoleuca: en jämförelse mellan vuxna fåglar och boungar. - Vår Fågelvärld 43: 517 524 (in Swedish).

Silvola, T. 1967: Changes in the bird populations in Utsjoki, Finnish Lapland in 1964-1966, caused by the massoccurrence of the caterpillar Oporinia autumnata. Ornis Fenn. 44: 65-67 (in Finnish, English summary).

Spidsø, T. K. 1980: Food selection by willow grouse (Lagopus lagopus) chicks in northem Norway, _ Omis 
Scand. 11: 99-105.

Spids $\emptyset$, T. K. \& Stuen, O. H. 1988: Food selection by capercaillie chicks in southern Norway. - Can. J. Zool. 66: 279-283.

Stuen, O. H. 1983: Storfuglkyllingenes (Tetrao urogallus) naeringsvalg i Vegårshei om sommaren. - M. Sc. thesis, Agricultural University of Norway, Ås, Norway, $38 \mathrm{pp}$. (in Norwegian).

Stuen, O. H. \& Spids $\varnothing$, T. K. 1988: Invertebrate abundance in different forest habitats as animal food available to capercaillie Tetrao urogallus chicks. — Scand. J. For. Res. 3: 527-532.

Thiollay, J. - M. 1988: Comparative foraging success of insectivorous birds in tropical and temperate forests: ecological implications. - Oikos 53: 17-30.

Tinbergen, L. 1960: The natural control of insects in pinewoods. I. Factors influencing the intensity of predation by songbirds. - Arch. Néerland. Zool. 13:
265-343.

Tomialojc, L. \& Wesolowski, T. 1990: Bird communities of the primeval temperate forest of Bialowieza, Poland. - In Keast, A. (ed.): Biogeography and ecology of forest bird communities. SPB Academic Publishing bv, The Hague, The Netherlands, pp. 141-165.

Topping, C. J. \& Sunderland, K. D. 1992: Limitations to the use of pitfall traps in ecological studies exemplified by a study of spiders in a field of winter wheat. J. Appl. Ecol. 29: 485-491.

Törmälä, T. 1982: Evaluation of five methods of sampling field layer arthropods, particularly the leafhopper community, in grassland, - Ann. Entomol. Fenn, 48: 1-16. Wilkinson, L. 1987: SYSTAT: The system of statistics. Systat Inc., Evanston, IL. 822 pp.

Zar, J. H. 1984: Biostatistical analysis. - Prentice-Hall International, Inc., Engelwood Cliffs, New Jersey, USA. 718 pp. 